\title{
Correlation of facial anthropometry data of late preterm newborns and oral feeding readiness
}

\section{Correlação de dados de antropometria facial de recém-nascidos prematuros tardios e prontidão para alimentação oral}

Correlación de datos de antropometría facial de neonatos prematuros tardíos y prontitud para alimentación por vía oral

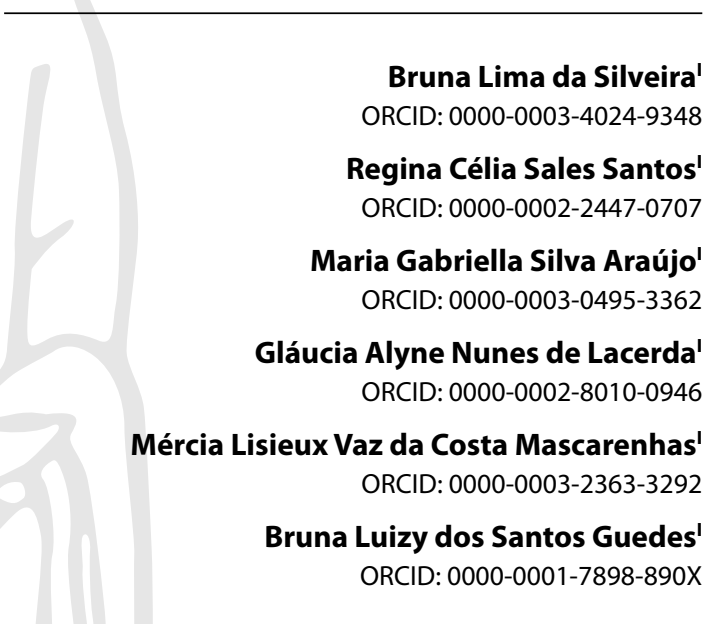

'Universidade Federal de Alagoas. Maceió, Alagoas, Brazil.

How to cite this article:

Silveira BL, Santos RCS, Araújo MGS, Lacerda GAN,

Mascarenhas MLVC, Guedes BLS. Correlation of facial anthropometry data of late preterm newborns and oral feeding readiness. Rev Bras Enferm. 2021;74(5):e20201120. https://doi.org/10.1590/0034-7167-2020-1120

\section{Corresponding author: Bruna Lima da Silveira \\ E-mail: bruna_Ids@hotmail.com}

EDITOR IN CHIEF: Antonio José de Almeida Filho ASSOCIATE EDITOR: Alexandre Balsanell

Submission: $11-08-2020$

Approval: 02-18-2021

\section{ABSTRACT}

Objective: To correlate nine facial anthropometric measurements with the readiness for oral feeding of late preterm newborns using an orogastric tube. Methods: Observational study, carried out in two institutions in Maceió, Alagoas. Fifty-two newborns participated. A single measuring of nine facial measurements and daily measuring of the interface area for fixing the tube was performed. For readiness assessment, the Premature Oral Feeding Readiness Assessment Scale was used. Results: An average readiness of $28.81( \pm 3.18)$ was observed in the first evaluation and $30.65( \pm 3.23)$ in the second. Most facial measurements are correlated with weight. There was a positive and slight correlation between glabellasubnasale distance and readiness. No correlation was observed between the area of the tube fixation interface and facial measurements. Conclusion: It is concluded that the glabellasubnasale measurement is positively correlated with the readiness for oral feeding in late preterm newborns who used an orogastric tube for feeding.

Descriptors: Preterm Newborn; Sucking Behavior; Anthropometry; Breast Feeding; Data Correlation.

\section{RESUMO}

Objetivo: Correlacionar nove medidas antropométricas faciais com a prontidão para alimentação oral de recém-nascidos prematuros tardios utilizando sonda orogástrica. Métodos: Estudo observacional, realizado em duas instituições de Maceió, Alagoas. Participaram 52 recémnascidos. Efetuou-se mensuração única de nove medidas faciais e mensuração diária da área da interface para fixação da sonda. O Instrumento de Avaliação da Prontidão do Prematuro para Início da Alimentação Oral foi utilizado para avaliação da prontidão. Resultados: Observouse média de prontidão de $28,81( \pm 3,18)$ na primeira avaliação e $30,65( \pm 3,23)$ na segunda. A maioria das medidas faciais estão correlacionadas com o peso. Houve correlação positiva e leve entre a distância glabela-subnasal e a prontidão. Não foi observada correlação entre a área da interface de fixação da sonda com as medidas faciais. Conclusão: Conclui-se que a medida glabela-subnasal está correlacionada positivamente com a prontidão para alimentação oral em recém-nascidos prematuros tardios que utilizaram sonda orogástrica para alimentação. Descritores: Recém-Nascido Prematuro; Comportamento de Sucção; Antropometria; Aleitamento Materno; Correlação de Dados.

\section{RESUMEN}

Objetivo: Correlacionar nueve medidas antropométricas faciales a la prontitud para alimentación por vía oral de neonatos prematuros tardíos utilizando sonda orogástrica. Métodos: Estudio observacional, realizado en dos instituciones de Maceió, Alagoas. Participaron 52 neonatos. Realizó medición única de nueve medidas faciales y medición diaria del área de la interface para fijación de sonda. Instrumento de Evaluación de la Prontitud del Prematuro para Inicio de Alimentación Oral utilizado para evaluación de prontitud. Resultados: Observó mediana de prontitud de $28,81( \pm 3,18)$ en la primera evaluación y $30,65( \pm 3,23)$ en la segunda. Mayoría de las medidas faciales están correlacionadas al peso. Hubo correlación positiva y leve entre la distancia glabela-subnasal y la prontitud. No observó correlación entre la área de la interface de fijación de sonda con las medidas faciales. Conclusión: La medida glabela-subnasal está correlacionada positivamente con la prontitud para alimentación oral en neonatos prematuros tardíos que utilizaron sonda orogástrica para alimentación.

Descriptores: Recién Nacido Prematuro; Conducta en la Lactancia; Antropometría; Lactancia Materna; Correlación de Datos. 


\section{INTRODUCTION}

Prematurity is one of the biggest challenges in perinatal care, being an important cause of neonatal morbidity and mortality ${ }^{(1)}$, since premature newborns can present critical health conditions and several complications ${ }^{(2)}$.

Preterm newborns have neurological immaturity, little capacity for self-regulation, absent or weak oral reflexes, among other particularities that can influence oral feeding ability ${ }^{(3)}$.

Late preterm infants represent the majority of premature infants. Despite the close to term gestational age, they also experience difficulties in learning to breastfeed, since they still present immature physiological characteristics ${ }^{(4)}$. In addition, they are more subject to inflammatory lesions and oxidative stress, which emphasizes the importance of breastfeeding for their protection ${ }^{(5)}$.

Readiness for oral feeding is the capacity or ability to feed orally, especially on the mother's breast. Initially, many newborns do not have the conditions or readiness for oral feeding. The presence of limitations and difficulties in the food transition process highlights the importance of the role of health professionals to ensure the success of this process. In such circumstances, nursing professionals work throughout the hospitalization, offering food at the beginning of the process, and enabling practices that stimulate, encourage, and facilitate a safe food transition.

For the process of safely feeding the preterm newborn, it is necessary to provide integrated care to the professional team, working collaboratively in order to promote favorable conditions for encouraging oral feeding and learning to breastfeed. Continuous assessment of the mother-child binomial is essential, allowing the team to identify possible difficulties at an early stage, intervene to facilitate this process, and promote the encouragement of oral feeding as soon as possible, in order to smoothly transition feeding to the mother's breast.

Thus, continuous assessment of the newborn's readiness for oral feeding related aspects is of great importance for their safety in the process of food transition, since oral skills can progress, regress, or remain at a constant pace as the newborn experiences contact with the mother's breast and milk ${ }^{(6)}$. In assessing readiness for oral feeding, some aspects should be considered: corrected age, behavioral organization (state of consciousness, posture, and overall tone), oral posture (posture of lips and tongue), presence of oral reflexes (searching, sucking, biting, and vomiting), tongue and jaw movements, suction pattern and strength, and presence of signs of stress ${ }^{(7)}$.

Therefore, it is necessary that professionals involved in this process (nurses, nursing technicians, speech therapists, physiotherapists, nutritionists, doctors, psychologists, occupational therapists, among others) be trained to safely guide, assist, and support the mother and child binomial, as well as correctly assessing aspects that may interfere with oral feeding readiness and the initiation and maintenance of breastfeeding in these newborns.

Thus, monitoring the newborn's orofacial growth and development is of great importance, as orofacial changes can interfere with the act of breastfeeding. Thereafter, this monitoring must be performed by health professionals, and one of the monitoring strategies is to carry out face measurements, so that, when appropriate, interventions that facilitate breastfeeding learning and the process of feeding transition from one to the next are done for newborns with a higher risk of having difficulties during the process.

It is noticed that studies with the neonatal population addressing specific evaluation issues are still scarce; and, in practice, techniques used in adults have been used to assess newborns. The limited production of studies that address specific anthropometric measures for newborns generates a knowledge gap whose filling could prove the effectiveness of practices and assist professionals during care.

Thus, it is necessary to carry out research that evaluates the anatomical characteristics of newborns as a parameter for clinical decision in the process of food transition, since facial measurements are important for determining orofacial morphology ${ }^{(8)}$ and to identify changes that may influence stomatognathic functions. Bearing in mind that breastfeeding involves some of these functions, the question arises as to how the newborn's facial anthropometric measurements can correlate with the readiness for oral feeding.

\section{OBJECTIVE}

To correlate nine facial anthropometric measurements with the readiness for oral feeding of late preterm newborns using an orogastric tube.

\section{METHODS}

\section{Ethical aspects}

The study was approved by the Research Ethics Committee of the Federal University of Alagoas, with respect to the provisions of Resolution 466/2012 and 510/2016 of the National Health Council on research with human beings.

After invitation and consent for the newborn's participation in the research, the participants' custodians signed the Free and Informed Consent Form (ICF).

\section{Study design, period, and location}

Observational study, guided by the STROBE tool and carried out in two medium and high complexity institutions in obstetric and neonatal care located in Maceió, Alagoas, from August 2019 to March 2020. It was extracted from a cohort study that aimed to determine whether the fixation of the orogastric tube in the temporomandibular region in late preterm newborns optimizes the readiness for oral feeding when compared with other types of fixation.

\section{Population}

The study participation eligibility criteria were premature newborns, 34 to 36 weeks and 6 days old, using an orogastric tube as a means of feeding. Excluded from the research were: Newborns who had congenital head and neck malformations, genetic syndromes, significant neurological disorders (intracranial hemorrhage grade III and IV, hydrocephalus), moderate and severe perinatal asphyxia (with an Apgar score of less than or equal to 5 in the fifth minute of life), who made use of invasive mechanical ventilation, who used an interface to fix devices other than the face orogastric tube, maternal or neonatal conditions that contraindicated breastfeeding, and newborns using ventilatory support at the time of observation. 
Fifty-two newborns who used an orogastric tube as a means of feeding participated in the study. The sample calculation was done for the primary study, with 26 newborns per group, and the sample size was calculated based on the study by Fujinaga ${ }^{(9)}$, considering the proportion of $30.39 \%$ and $2.9 \%$ among groups of newborns in a state of deep sleep and alertness respectively, with a significance level of $5 \%$ and two-tailed test power of $80 \%$. Only the sample of 52 newborns was considered in this article.

\section{Study protocol}

Newborns were included in the study when admitted to a neonatal unit, shortly after birth, ending their participation hours after beginning their food transition. They were included when using a gastric tube, being observed until they started the food transition, when the evaluations related to the readiness for oral feeding of the participants occurred. The studied variables were: facial anthropometric measurements, readiness for oral feeding, measurement of the area of the orogastric tube fixation, sex, and weight.

When assessing readiness for oral feeding, the newborn could be using a gastric tube (orogastric or nasogastric) or not. In addition, there was no record of intervention of sensorimotor stimuli of the participants, which may be confounding factors in this study.

A single measuring of nine facial anthropometric measurements was performed: 1) Trichion (tr) and glabella (g) distance; 2) Glabella (g) and subnasale (sn) distance; 3 ) Subnasale (sn) and mentonian (me) distance; 4) Byzigomatic distance (zid-zie), from the right zygomatic point to the left zygomatic point; 5) Bigonial distance (god-goe), from the right gonion point to the left gonion point; 6) Subnasale (sn) and stomion (sto) distance; 7) Mentonian (me) and stomion distance (sto); 8) Right zygomatic (zid) and stomion (sto) distance, and 9) Left zygomatic (zie) and stomion (sto) distance.

The points used to measure the distances were: trichion, located in the hair implantation, in the midline of the forehead; glabella, most prominent point on the midline between the eyebrows; subnasale, median point of the angle of the base of the columella, at the meeting of the lower edge of the nasal septum with the surface of the upper lip; mentonian, the lowest point of the mentonian symphysis; zygomatic, most prominent point on the lateral face of the zygomatic bone; gonion (go), the most inferior and posterior point of the mandible; stomion (sto), point located at the intersection between the vertical median line and the horizontal line of the slit of the mouth, while lips are closed.

The measuring of the face measurements was performed by two evaluators and occurred with the newborn in the supine position. The head, then, was centered. A flexible ruler was used to mark the reference points; and with a measuring tape, the measurement was performed between the points. The measurements were obtained without pressing the materials on the newborn's skin surface. The measuring tape and the ruler are measuring instruments with an accuracy of 0.1 millimeter. Facial measurements were recorded in centimeters.

Daily measuring of the interface area was also performed on the newborn, while in use of an orogastric tube, with the aid of a measuring tape. Its registration was made in square centimeters $\left(\mathrm{cm}^{2}\right)$. The interfaces used were made of hydrocolloid or microporous tape and adhered to the newborn's skin. Measures were taken to ensure newborn comfort throughout all data collection. The measuring tape and rulers were washed with soap and water and disinfected with $70 \%$ alcohol each time.

In the observation of oral feeding readiness, two evaluations were performed with a minimum interval of 24 hours. The first occurred from the beginning of the food transition until 21 hours later. The second took place 24 to 45 hours after the first evaluation. Both were performed with the aid of the Premature Oral Feeding Readiness Assessment Scale - POFRAS ${ }^{(10)}$.

The readiness assessment must occur by noting the presence and quality of behavioral, neuromotor, tactile responses, and physiological control parameters. POFRAS is a validated instrument with the objective of evaluating performance elements of the preterm newborn regarding readiness for oral feeding. It has 18 performance items for oral feeding divided into five categories: corrected age ( $\leq 32$ weeks; $32-34$ weeks; and $\geq 34$ weeks), state of behavioral organization (state of consciousness, global posture, and global tone), oral posture (lip posture, tongue posture), oral reflexes (searching, suction, bite, and vomit reflex), non-nutritive sucking (tongue movement, tongue cannulation, jaw movement, suction force, sucking pauses, maintenance of rhythm, maintenance of alertness, signs of stress). The signs of stress observed are: accumulation of saliva, flapping of the nasal wing, variation in skin color, apnea, variation in tone, variation in posture, circulation, tremors of the tongue or jaw, hiccups, and crying. It has a minimum score of 0 and a maximum of 36 points. For analysis, the average of the total score obtained during the evaluation was used.

The assessment took place by observing the newborn's state of behavioral organization, oral posture, and performing nonnutritive sucking. The latter is performed by introducing the appraiser's gloved little finger into the newborn's oral cavity, which is in a neutral position.

\section{Analysis of results and statistics}

The collected data were tabulated in a Microsoft Excel ${ }^{\circledR}$ spreadsheet and analyzed using the Statistical Package for the Social Sciences - SPSS ${ }^{\circledR}$ software, version 20.

For the descriptive statistical analysis, the following were calculated: mean, standard deviation, and standard error of the mean. Inferential analysis was performed using Student's $t$ test, Mann-Whitney test; Pearson's correlation test and Spearman's correlation test. For the analyses, the differences between the groups were considered significant with $p$ values $\leq 0.05$.

\section{RESULTS}

Seventy newborns were recruited according to the inclusion and exclusion criteria. As this is a replacement sample, 52 newborns participated in the research. There were five losses due to changing the fixation location during follow-up; five due to the need to transfer the newborn to other institutions; two due to clinical worsening; one due to the presence of intracranial hemorrhage during follow-up; and five losses due to the researcher's limitations in maintaining the follow-ups. 
Of the participating newborns, 51.9\% were male; and $48.1 \%$, female. When carrying out the analysis of the means of anthropometric measurements of the faces of the newborns in relation to sex, it is noticed that the values remain similar between the two sexes for almost all distances. Only the bigonial distance, which extends from the right to the left gonion, was significantly different between the sexes $(p=0.047)$, with an average of 6.96 $( \pm 0.97)$ in females and $6.41( \pm 0.91)$ in males (Table 1$)$.

Table 1 - Association between sex and anthropometric face measurements of newborns, Maceió, Alagoas, Brazil, 2020

\begin{tabular}{|c|c|c|c|c|c|}
\hline \multirow{3}{*}{$\begin{array}{l}\text { Anthropometric face } \\
\text { measurements }\end{array}$} & \multicolumn{4}{|c|}{ Sex } & \multirow{3}{*}{$\underset{\text { value* }}{p}$} \\
\hline & \multicolumn{2}{|c|}{ Female $n=25$} & \multicolumn{2}{|c|}{ Male $\mathbf{n}=\mathbf{2 7}$} & \\
\hline & $\begin{array}{l}\text { Mean } \\
( \pm s d)\end{array}$ & SEM & $\begin{array}{l}\text { Mean } \\
( \pm s d)\end{array}$ & SEM & \\
\hline tr-g distance & $2.57(0.54)$ & 0.10 & $2.36(0.52)$ & 0.10 & 0.167 \\
\hline g-sn distance & $3.27(0.38)$ & 0.07 & $3.28(0.35)$ & 0.06 & 0.934 \\
\hline sn-me distance & $2.94(0.43)$ & 0.08 & $2.72(0.36)$ & 0.07 & 0.055 \\
\hline zid-zie distance & $7.54(0.89)$ & 0.17 & $7.21(0.75)$ & 0.14 & 0.167 \\
\hline god-goe distance & $6.96(0.97)$ & 0.19 & $6.41(0.91)$ & 0.17 & 0.047 \\
\hline sn-sto distance & $1.28(0.30)$ & 0.06 & $1.26(0.21)$ & 0.04 & 0.886 \\
\hline me-sto distance & $1.71(0.36)$ & 0.07 & $1.54(0.34)$ & 0.06 & 0.088 \\
\hline zid-sto distance & $4.76(0.62)$ & 0.12 & $4.44(0.48)$ & 0.09 & 0.042 \\
\hline zie-sto distance & $4.77(0.69)$ & 0.13 & $4.42(0.50)$ & 0.09 & $0.069^{* *}$ \\
\hline
\end{tabular}

Note: tr-g: trichion-glabella; $g$-sn: glabella-subnasale; sn-me: subnasale-mentonian; zid-zie: right zygomatic-left zygomatic; god-goe: right gonion- left gonion; sn-sto: subnasale-stomion; me-sto: mentonian-stomion; zid-sto: right zygomatic-stomion; zie-sto: left zygomatic-stomion; sd: standard deviation; SEM: standard error of the mean. ${ }^{*}$ Student's t test $p$-value; ${ }^{* *} p$-value of the Mann-Whitney test. Statistical significance was considered when $p \leq 0.05$.

The average weight of newborns who participated in the study was $2,141.35 \mathrm{~g}( \pm 543.83)$ with a minimum weight of $1,287 \mathrm{~g}$ and $\mathrm{a}$ maximum weight of $3,850 \mathrm{~g}$. Discordant with age, weight proved to be a measure that correlated with almost all the evaluated facial anthropometric measures. In both evaluations, a slight positive correlation was observed with the trichion-glabella distance, which extends between the implantation of the hair (in the midline of the forehead) to the most prominent point in the midline between the eyebrows $(p=0.012 ; p=0.004)$ and with the subnasale-mentonian distance that is from the median point of the angle of the columellar base to the lowest point of the mentonian symphysis $(p=0.024 ; p=0.032$ ) (Table 2 ).

Table 2 - Correlation between face and weight measurements in the first and second assessment with the Premature Oral Feeding Readiness Assessment Scale, POFRAS, Maceió, Alagoas, Brazil, 2020

\begin{tabular}{|c|c|c|c|c|c|}
\hline \multirow{3}{*}{$\begin{array}{l}\text { Anthropometric face } \\
\text { measurements }\end{array}$} & \multicolumn{5}{|c|}{ Weight (grams) } \\
\hline & \multirow{2}{*}{$\begin{array}{l}\text { Mean } \\
( \pm s d)\end{array}$} & \multicolumn{2}{|c|}{$1^{\text {st }}$ evaluation } & \multicolumn{2}{|c|}{$2^{\text {nd }}$ avaliação } \\
\hline & & $\mathbf{R t}$ & $p$ value* & Rt & $p$ value* \\
\hline tr-g distance & $2.47(0.54)$ & 0.348 & 0.012 & 0.398 & 0.004 \\
\hline g-sn distance & $3.27(0.36)$ & 0.180 & 0.206 & 0.195 & 0.170 \\
\hline sn-me distance & $2.83(0.40)$ & 0.315 & 0.024 & 0.300 & 0.032 \\
\hline zid-zie distance & $7.38(0.82)$ & 0.672 & 0.000 & 0.693 & 0.000 \\
\hline god-goe distance & $6.69(0.97)$ & 0.672 & 0.000 & 0.676 & 0.000 \\
\hline sn-sto distance & $1.27(0.26)$ & 0.411 & 0.003 & 0.466 & 0.001 \\
\hline me-sto distance & $1.63(0.36)$ & 0.353 & 0.011 & 0.340 & 0.015 \\
\hline zid-sto distance & $4.60(0.56)$ & 0.568 & 0.011 & 0.581 & 0.000 \\
\hline zie-sto distance & $4.59(0.62)$ & $0.619 \dagger$ & $0.000^{* *}$ & $0.619+$ & $0.000^{* *}$ \\
\hline
\end{tabular}

Note: tr-g: trichion-glabella; $g$-sn: glabella-subnasale; sn-me: subnasale-mentonian; zid-zie: right zygomatic-left zygomatic; god-goe: right gonion-left gonion; sn-sto: subnasale-stomion; me-sto: mentonian-stomion; zid-sto: right zygomatic-stomion; zie-sto: left zygomatic-stomion; $s d$ : standard deviation. * P-value of Pearson's correlation test; Pearson's $+R$; ** $p$-value of Spearman's correlation test; Spearman's $+R h o$. Statistical significance was considered when $p \leq 0.05$.
A moderate positive correlation of weight was observed with some distances in both evaluations, they are: byzygomatic distance, which starts from the right zygomatic point to the left zygomatic point ( $p=0.000 ; p=0.000)$, with an average of $7.38(0.82) \mathrm{cm}$; bigonial distance $(p=0.000 ; p=0.000)$, with an average of $6.69( \pm 0.97) \mathrm{cm}$; subnasale-stomion distance, which runs from the median point of the angle of the base of the columella to the point located at the intersection between the vertical line, median, and the horizontal line of the slit of the mouth $(p=0.003 ; p=0.001)$, with an average of 1.27 $( \pm 0.26) \mathrm{cm}$; mentonian-estonian distance, which is from the same estonian point and goes down to the lowest point of the mentonian symphysis ( $p=0.011 ; p=0.015)$, with an average of $1.63( \pm 0.36) \mathrm{cm}$; right zygomatic distance, which is also distant from the stomion but now towards the right zygomatic point $(p=0.001 ; p=0.000)$, with an average of $4.60( \pm 0.56)$ $\mathrm{cm}$; left-stomion zygomatic distance, contralateral measure of right- stomion zygomatic distance $(p=0.000 ; p=0.000)$; with an average of $4.59( \pm 0.62) \mathrm{cm}$.

The glabella-subnasale distance, which runs from the most prominent point on the median line between the eyebrows to the median point of the angle at the base of the columella, was the only measure that did not show a correlation with weight in any of the two assessments, including maintaining the mean in that time interval $(3.27 \pm 0.36)$.

During the analysis of readiness scores, the study showed that the average final readiness score was 28.81 ( \pm 3.18 ) points, with a minimum score of 20 and a maximum of 35 points in the first assessment; and 30.65 ( \pm 3.23 ) points, with the lowest score of 23 and higher than 35 points in the second assessment. When analyzing the correlation between the anthropometric measurements of the newborn's face and the averages of readiness, a slight positive correlation was observed between the glabellasubnasale distance and the readiness for oral feeding; thus, the greater the measures of this distance, the greater the readiness values (Table 3). The other measures have no significant correlation with readiness.

Table 3 - Correlation between total assessed score of readiness for oral feeding with Premature Oral Feeding Readiness Assessment Scale and anthropometric measurements of the face, Maceió, Alagoas, Brazil, 2020

\begin{tabular}{|c|c|c|c|c|c|}
\hline \multirow{3}{*}{ Face measures } & \multirow{3}{*}{$\begin{array}{l}\text { Mean } \\
( \pm s d)\end{array}$} & \multicolumn{4}{|c|}{$\begin{array}{l}\text { Total score of readiness for oral } \\
\text { feeding }\end{array}$} \\
\hline & & \multicolumn{2}{|c|}{$\begin{array}{l}\text { Readiness } \\
1^{\text {st }} \text { Evaluation }\end{array}$} & \multicolumn{2}{|c|}{$\begin{array}{l}\text { Readiness } \\
2^{\text {nd }} \text { Evaluation }\end{array}$} \\
\hline & & $\mathbf{R} \boldsymbol{T}$ & $p$ value* & Rt & $p$ value* \\
\hline tr-g distance & $2.48(0.56)$ & -0.57 & 0.351 & 0.045 & 0.381 \\
\hline g-sn distance & $3.28(0.37)$ & 0.350 & 0.007 & 0.359 & 0.006 \\
\hline sn-me distance & $2.82(0.41)$ & 0.008 & 0.480 & 0.146 & 0.325 \\
\hline zid-zie distance & $7.39(0.86)$ & 0.222 & 0.065 & 0.325 & 0.012 \\
\hline god-goe distance & $6.70(0.99)$ & 0.055 & 0.356 & 0.235 & 0.054 \\
\hline sn-sto distance & $1.29(0.26)$ & 0.038 & 0.398 & 0.026 & 0.431 \\
\hline me-sto distance & $1.63(0.36)$ & -0.023 & 0.440 & 0.210 & 0.076 \\
\hline zid-sto distance & $4.58(0.57)$ & 0.036 & 0.403 & 0.233 & 0.055 \\
\hline zie-sto distance & $4.57(0.62)$ & $-0.005 t$ & $0.485^{* *}$ & $0.156 t$ & $0.146^{* *}$ \\
\hline
\end{tabular}

Note: tr-g: trichion-glabella; $g$-sn: glabella-subnasale; sn-me: subnasale-mentonian; zid-zie: right zygomatic-left zygomatic; god-goe: right gonion- left gonion; sn-sto: subnasale-stomion; me-sto: mentonian-stomion; zid-sto: right zygomatic-stomion; zie-sto: left zygomatic-stomion sd: standard deviation. * $P$-value of Pearson's correlation test; Pearson's $t R$; ** $p$-value of Spearman's correlation test; Spearman's $+R h o$. Statistical significance was considered when $p \leq 0.05$. 
The analysis of the area of the tube attachment interface in newborns was carried out in order to identify whether there was any attention from nursing professionals with the proportionality of the interface size in relation to the anthropometric measurements of the newborn's face. These interfaces were of non-standard sizes, made by nurses as part of their routine of the studied institutions, with an average of $0.97(0.99) \mathrm{cm}^{2}$. It was identified that there was no correlation between the area of the interface used for fixing the tube and the face measurements, as observed in Table 4.

Table 4 - Correlation between the area of the orogastric tube fixation interface in the face and the anthropometric face measurements, Maceió, Alagoas, Brazil, 2020

\begin{tabular}{|c|c|c|c|}
\hline \multirow[t]{2}{*}{ Variables } & \multirow{2}{*}{$\begin{array}{l}\text { Mean } \\
( \pm s d)\end{array}$} & \multicolumn{2}{|c|}{$\begin{array}{l}\text { Area of the orogastric tube } \\
\text { fixation interface in the face }\end{array}$} \\
\hline & & Rt & $p$ value* \\
\hline tr-g distance & $2.48(0.56)$ & -0.101 & 0.493 \\
\hline g-sn distance & $3.28(0.37)$ & 0.159 & 0.279 \\
\hline sn-me distance & $2.82(0.41)$ & 0.032 & 0.831 \\
\hline zid-zie distance & $7.39(0.86)$ & -0.189 & 0.198 \\
\hline god-goe distance & $6.70(0.99)$ & -0.139 & 0.345 \\
\hline sn-sto distance & $1.29(0.26)$ & -0.159 & 0.281 \\
\hline me-sto distance & $1.63(0.36)$ & 0.075 & 0.612 \\
\hline zid-sto distance & $4.58(0.57)$ & -0.133 & 0.367 \\
\hline zie-sto distance & $4.57(0.62)$ & $-0.117 \dagger$ & $0.429 * *$ \\
\hline
\end{tabular}

Note: tr-g: trichion-glabella; $g$-sn: glabella-subnasale; sn-me: subnasale-mentonian; zid-zie: right zygomatic-left zygomatic; god-goe: right gonion-left gonion; sn-sto: subnasale-stomion; me-sto: mentonian-stomion; zid-sto: right zygomatic-stomion; zie-sto: left zygomatic-stomion $s d$ : standard deviation; * P-value of Pearson's correlation test; Pearson's $+R$; ** $p$-value of Spearman's correlation test; Spearman's $+R$ ho. Statistical significance was considered when $p \leq 0.05$.

\section{DISCUSSION}

The newborns had a similar distribution when observed in terms of sex, with no correlation between sex and the evaluated face measurements, except for bigonial distance (god-goe). Females had higher averages of this distance. Higher bigonial measurements may be related to the configuration of the musculature and orofacial structures, as well as to the stomatognathic functions exercised by the individual. Considering this finding, other studies ${ }^{(8-11)}$ also showed the possibility of a relationship between elevated horizontal dimensions and the configuration of orofacial structures.

A study that evaluated orofacial measurements according to the facial type in children aged 7 to 11 years old obtained a higher frequency of brachyfacials (horizontal growth greater than vertical), followed by mesofacials (vertical growth symmetrical to horizontal) and, to a lesser extent, dolichofacials (vertical growth greater than horizontal). And, when observed by sex, it was noticed that almost half of the girls were brachyfacial, while the boys were distributed in a similar way among the three facial typologies ${ }^{(11)}$.

Another study that evaluated full-term newborns found a difference between male and female in the measurements of the upper and lower lip, and filter, which were higher in males. The association between upper lip (subnasale-stomion) and lower lip (stomion-gnathion), upper facial third (trichion-glabella) and middle third (glabella-subnasale), between middle third (glabellasubnasale) and lower third (subnasale-gnathion), did not present significance between the $\operatorname{sexes}^{(8)}$.
Almost all face measurements evaluated were associated with the newborn's weight, both in the first and in the second evaluation. The glabella-subnasale distance was the only distance in which no correlation was perceived. In general, the evaluated measures showed a positive correlation of mild or moderate degree. Thus, the increase in weight determines the increase in the facial measures found. The increase in weight and, consequently, in body proportions, may be related to the increase in orofacial musculature.

Premature newborns may have changes in posture and muscle tone when they are very low weight, including changes in sucking, swallowing, nasal breathing, and lip, tongue, and orofacial muscle movements ${ }^{(12)}$.

A study that compared facial measurements in preterm and full-term newborns demonstrated that the former had lower vertical and horizontal face measurements when compared to full-term newborns. The preterm newborns had higher values in the upper third, followed by the lower and middle thirds ${ }^{(13)}$. With this, it is seen that prematurity can be a defining component for risks of growth and development of facial thirds.

Research that evaluated individuals between 6 and 14 years of age with obstructive sleep apnea, who were born prematurely and at term, concluded that premature newborns have a different craniofacial morphology when compared to term newborns, suggesting dolichofacial morphology $\mathrm{y}^{(14)}$.

In this study, the glabella-subnasale measure had a positive correlation with readiness for oral feeding, with greater distances related to higher averages of readiness. The mechanisms used for breastfeeding are predominantly used in orofacial morphology. Better developed nasal structures favor adequate breathing and the action of extracting milk from the breast. Thus, it is suggested that greater glabella-subnasale distances may be related to betterdeveloped nasal structures, similar to those of full-term newborns, which may favor respiratory function during breastfeeding. Thus, these newborns tend to have greater readiness when compared to those with short glabella-subnasale distances.

The mechanisms used during breastfeeding are related to the adequate development of orofacial structures ${ }^{(15)}$, since the muscular action during the act promotes growth of these structures and the face with a positive impact on the functions of the stomiontognathic system. Literature demonstrates that a longer time breastfeeding decreases the chances of the presence of oral breathing patterns in children ${ }^{(16-17)}$.

A study that compared anthropometric measurements (upper lip, lower lip, filter, upper face, middle face, lower face, and sides of the face) of mouth breathing children with nasal breathing children, between 7 and 11 years of age, demonstrated a significant difference between most measures of face between the studied groups ${ }^{(18)}$.

It is necessary for the multiprofessional health team to monitor the newborn's orofacial growth and development to intervene in advance and reestablish adequate orofacial physiology ${ }^{(13)}$, including interventions that enable the achievement of readiness for oral feeding.

Thus, the evaluation of face measurements can be an indicator for decision making in view of the difficulties in the food transition process. The detection of short facial measurements of the middle 
third of the face implies the establishment of early strategies to facilitate the care of the newborn, especially the premature, who, due to their particularities, have a greater risk of presenting difficulties in readiness for oral feeding. It is important to monitor this newborn during food transition, to monitor its evolution, and observe possible difficulties in order to offer strategies that favor the learning of breastfeeding.

No relation was observed between the area of the interface used for fixing the tube and the evaluated facial measurements. The interfaces used were of non-standard sizes. The size of the interface to be used for fixing orogastric tubes in newborns is an important criterion to be evaluated when performing the orogastric tube procedure, since its use can lead to complications that are often preventable. The use of small fixation interfaces provides greater comfort and safety to the newborn when compared to larger sizes, in addition to reducing the risk of restriction of facial muscles.

Nurses can use newborns' facial measures to standardize criteria for interface sizes, in order to reduce complications and favor readiness for feeding and breastfeeding.

\section{Study limitations}

The study had the following limitations: 1) newborns were assessed for readiness regardless of the presence of a gastric tube at the time of assessment and 2) no record of the sensorimotor stimulus intervention. Therefore, these are possible confounding variables in the study.

\section{Contributions to the Nursing field}

The evaluation of facial measures in newborns emerges as a strategy for individualized neonatal care. Through the evaluation of these measures, especially of the glabella-subnasale distance, it will be possible for nurses to intervene early, in order to help the newborn who has a reduced middle third of the face, with the introduction of facilitating strategies for learning to breastfeed and consequent readiness for oral feeding.

In addition, the result can be used as a parameter for other studies that investigate newborns' facial anatomical distances and their relationship with stimulation strategies in order to optimize readiness for oral feeding.

\section{CONCLUSION}

It is concluded that the glabella-subnasale measurement is positively correlated with the readiness for oral feeding in late preterm newborns who used an orogastric tube for feeding; and that the absolute majority of the newborn's facial anthropometric measurements are correlated with weight (trichion-glabella, subnasale-mentonian, byzigomatic, bigonial, subnasale-stomion, mentonian-stomion, zygomatic right-stomion, and zygomatic left-stomion).

Thus, the observation of facial measures during newborn care can help detect possible difficulties in the food transition process, which can be reversed or minimized with the use of stimulation strategies and techniques for learning to breastfeed.

\section{REFERENCES}

1. World Health Organization (WHO). Survive and thrive: transforming care for every small and sick newborn [Internet]. Geneva (SWI): WHO; 2019 [cited 2020 Aug 29]. 150 p. Available from: https://apps.who.int/iris/handle/10665/276655?show=full

2. Yamamoto RCC, Prade LS, Bolzan GP, Weinmann ARM, Keske-Soares M. [Readiness for oral feeding and oral motor function in preterm infants]. Rev CEFAC. 2017;19(4):503-9. https://doi.org/10.1590/1982-0216201719411616 Portuguese.

3. Yamamoto RCC, Prade LS, Berwig LC, Weinmann ARM, Keske-Soares M. [Cardiorespiratory parameters and their relation with gestational age and level of oral feeding skills in preterm infants]. CoDAS. 2016;28(6):704-9. https://doi.org/10.1590/2317-1782/20162014221 Portuguese.

4. Lourenço N, Fernandes M, Gomes C, Resende C. Morbidade neonatal dos recém-nascidos pré-termo tardios comparados aos de termo precoce. Sci Med (Porto Alegre). 2017;27(1). https://doi.org/10.15448/1980-6108.2017.1.25876

5. Crippa BL, Colombo L, Morniroli D, Consonni D, Bettinelli ME, Spreafico I, et al. Do a few weeks matter? late preterm infants and breastfeeding issues. Nutrients. 2019;11(2):312. https://doi.org/10.3390/nu11020312

6. Griffith T, White-Traut R, Janusek LW. A behavioral epigenetics model to predict oral feeding skills in preterm infants. Adv Neonatal Care. 2020;20(5):392-400. https://doi.org/10.1097/ANC.0000000000000720

7. Bolzan GP, Berwig LC, Prade LS, Cuti LK, Yamamoto RCC, Silva AMT, et al. [Assessment for oral feeding in preterm infants]. CoDAS. 2016;28(3):284-8. https://doi.org/10.1590/2317-1782/20162015115 Portuguese.

8. Medeiros AMC, Santos KCF, Santi VN, Santos FB, Sereno BRS, Santana ARS, et al. Orofacial anthropometric measures in full-term newborn. CoDAS. 2019;31(6):e20180261. https://doi.org/10.1590/2317-1782/20192018261 Portuguese.

9. Fujinaga Cl, Maltauro S, Stadler ST, Cheffer ER, Aguiar S, Amorin NEZ, et al. [Behavioral state and the premature's readiness performance to begin oral feeding]. Rev CEFAC. 2018;20(1):95-100. https://doi.org/10.1590/1982-021620182015317 Portuguese.

10. Fujinaga Cl, Moraes SA, Zamberlan-Amorim NE, Castral TC, Silva AA, Scochi CGS. [Clinical validation of the Preterm Oral Feeding Readiness Assessment Scale]. Rev Latino-Am Enferm. 2013;21(spe):140-5. https://doi.org/10.1590/S0104-11692013000700018 Portuguese.

11. Berwig LC, Figueiredo FSP, Bolzan GP, Milanesi JM, Marquezan M, Busanello-Stella AR, et al. [Anthropometric orofacial measurements of children according to facial type]. Rev CEFAC. 2017;19(1):63-8. https://doi.org/10.1590/1982-0216201719111316 Portuguese. 
12. Amaizu N, Shulman R, Schanler R, Lau C. Maturation of oral feeding skills in preterm infants. Acta Paediatr [Internet]. 2008 [cited 2020 Sep 25];97(1):61-7. Available from: https://www.ncbi.nlm.nih.gov/pmc/articles/PMC2289993/pdf/nihms41663.pdf

13. Ruiz DR, Diniz EM, Krebs VL, Carvalho WB. Orofacial characteristics of the very low-birth-weight preterm infants. J Pediatr (Rio J). 2021;97(1):96-102. https://doi.org/10.1016/j.jped.2019.12.005

14. Lian YC, Huang YS, Guilleminault C, Chen KT, Hervy-Auboiron M, Chuang LC, et al. The preliminary results of the differences in craniofacial and airway morphology between preterm and full-term children with obstructive sleep apnea. J Dent Sci. 2017;12:253-60. https://doi. org/10.1016/j.jds.2017.03.005

15. Casagrande L, Ferreira FV, Hahn D, Unfer DT, Praetzel JR. Aleitamento natural e artificial e o desenvolvimento do sistema estomatogmático. Rev Fac Odontol (Porto Alegre) [Internet]. 2008 [cited 2020 Sep 25];49(2):11-7. Available from: https://seer.ufrgs.br/ RevistadaFaculdadeOdontologia/article/view/3032/8282

16. Rezende BA, Coelho PF, Lemos SMA, Medeiros AM. [Breastfeeding duration and sings of mouth breathing in children with poor school performance]. Distúrb Comun. 2019;31(1):69-76. https://doi.org/10.23925/2176-2724.2019v31i1p69-76 Portuguese.

17. Lopes TSP, Moura LFAD, Lima MCMP. Association between breastfeeding and breathing pattern in children: a sectional study. J Pediatr(RJ). 2014;90(4):396-402. https://doi.org/10.1016/j.jped.2013.12.011

18. Catonni DM, Fernandes FDM, Di Francesco RC, De-Latorre MRO. Quantitative evaluation of the orofacial morphology: anthropometric measurements in healthy and mouth-breathing children. Int J Orofacial Myology [Internet]. 2009 [cited 2020 Sep 25];35:44-54. Available from: https://pubmed.ncbi.nlm.nih.gov/20572437/ 